\title{
Not as clear as expected: what genetic data tell about Southern Hemisphere corellids (Ascidiacea: Phlebobranchia)
}

Gastón Alurralde, María Carla de Aranzamendi, Anabela Taverna, Tamara Maggioni \& Marcos Tatián

To cite this article: Gastón Alurralde, María Carla de Aranzamendi, Anabela Taverna, Tamara Maggioni \& Marcos Tatián (2018) Not as clear as expected: what genetic data tell about Southern Hemisphere corellids (Ascidiacea: Phlebobranchia), Journal of Natural History, 52:43-44, 2823-2831

To link to this article: https://doi.org/10.1080/00222933.2018.1553250

Published online: 21 Dec 2018.

Submit your article to this journal $\sqsubset$

View Crossmark data ¿ 


\title{
Not as clear as expected: what genetic data tell about Southern Hemisphere corellids (Ascidiacea: Phlebobranchia)
}

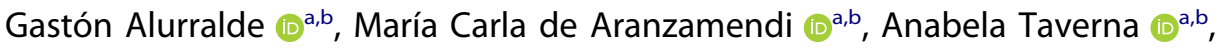 \\ Tamara Maggioni (10) ${ }^{\mathrm{a}, \mathrm{b}}$ and Marcos Tatián (10) \\ aUniversidad Nacional de Córdoba, Facultad de Ciencias Exactas, Físicas y Naturales, Ecología Marina, \\ Córdoba, Argentina; 'b Consejo Nacional de Investigaciones Científicas y Técnicas (CONICET), Instituto de \\ Diversidad y Ecología Animal (IDEA), Córdoba, Argentina
}

\begin{abstract}
The morphology of corellids (Ascidiacea) has led to numerous misidentifications and wrong taxonomic decisions over the last century. Paradoxically, the morphology has also enabled new species to be identified and ancient entities to be re-established in the Southern Hemisphere. There are many examples of the integration of morphological and molecular data leading to the same taxonomic conclusions, and therefore we aimed to analyse DNA sequences of the gene cytochrome oxidase subunit I of currently accepted species within Corellidae occurring in the Southern Hemisphere. Haplotype networks along with phylogenetic trees and genetic distances not only corroborate the distinction between Corella eumyota and Corella antarctica, but also separate the latter into two potential groups, one located in Terre Adélie and the other in the Antarctic Peninsula (AP). Furthermore, the $C$. antarctica group from the AP was closely related to the allied abyssal species, Corynascidia suhmi from Terre Adélie. Although the number of new sequences is reduced, our results are congruent with a long record of suspicion on the matter and stress the need for deeper and more extensive investigation of this ascidian family.
\end{abstract}

\section{ARTICLE HISTORY}

Received 2 May 2018

Accepted 21 November 2018

\section{KEYWORDS}

Ascidians; Corella; COI gene; Phylogeny; Taxonomy; Antarctic Peninsula; South America

\section{Introduction}

Species that belong to the family Corellidae (Ascidiacea: Phlebobranchia), and particularly those of the genus Corella, not only exhibit a wide range of morphological variability (Herdman 1910; Hartmeyer 1924; Ärnbäck-Christie-Linde 1938; Van Name 1945; Brewin 1946; Kott 1969; Lambert et al. 1981, 1995; Monniot 1994, 2013; Monniot and Monniot 1994; Sanamyan and Sanamyan 2002, 2005; Lambert 2004; Varela et al. 2007; Alurralde et al. 2013), but also present a similar range of genetic discrepancies (Dupont et al. 2007; Monniot et al. 2011). The most recent debate involved Corella eumyota Traustedt, 1882, a Corella species from southern South America and Antarctica (Alurralde et al. 2013; Monniot 2013), successfully invasive in the Northern Hemisphere (Lambert 2004; Arenas et al. 2006; Minchin 2007; Varela et al. 2007; Collin et al. 2010; Nagar et al. 2010) and with a high invasive potential in similar environments (Locke 2009). 
Corella eumyota is assumed to be native to the Southern Hemisphere and has long been considered widely distributed throughout this vast region, including Antarctica. Nevertheless, low allelic richness has been observed in populations of South Africa and New Zealand, which suggests that they may be the result of a more recent invasion (Dupont et al. 2007). Subsequently, Alurralde et al. (2013) re-established the Antarctic species, Corella antarctica Sluiter, 1905, based on morphological differences with its congener from Sub-Antarctic areas, while Monniot (2013) described a new species (Corella brewinae Monniot F., 2013) from New Zealand. Furthermore, Monniot et al. (2011) reported over $10 \%$ divergence among cytochrome oxidase subunit I (COI) mitochondrial gene sequences of $C$. antarctica (referred to as C. eumyota in that paper) and C. eumyota, but $93.75 \%$ similarity with Corynascidia suhmi Herdman, 1882, another corellid species. The morphology of $C$. eumyota and $C$. antarctica are clearly different (Alurralde et al. 2013; Monniot 2013), which raises the question of whether the morphological variation is genetically supported, and also what the genetic data may tell us in regard to Southern Hemisphere corellids. Molecular barcoding is an efficient tool for identifying species (Bucklin et al. 2011), and can help to detect misidentifications (McGlashan et al. 2008) or to support correct morphological identifications (Bishop et al. 2013). By gathering new COI sequences and merging them with published datasets, this study analysed genetic variation in corellid specimens occurring in southern South America (Argentina and Chile) and Antarctica.

\section{Material and methods}

Samples of C. eumyota were collected from Las Grutas (Argentina) and samples of C. antarctica from Potter Cove (25 de Mayo/King George Island, Antarctic Peninsula). Total genomic DNA was obtained from muscle tissue using the DNeasy Blood and Tissue kit (Qiagen, Hilden, Germany). A fragment of the mitochondrial gene COI was amplified using a universal primer pair (Folmer et al. 1994). Amplification was performed according to Turon et al. (2016). After initial denaturation ( $2 \mathrm{~min}, 94^{\circ} \mathrm{C}$ ), the PCR ran for $35 \mathrm{cycles}$ $\left(1 \mathrm{~min}, 94^{\circ} \mathrm{C} ; 1 \mathrm{~min}, 50^{\circ} \mathrm{C} ; 1 \mathrm{~min}, 72^{\circ} \mathrm{C}\right.$ ) with a terminal elongation of $7 \mathrm{~min}$ at $72^{\circ} \mathrm{C}$. The amplifications were sequenced by Macrogen Inc. (Seoul, Rep. of Korea). Only one specimen of $C$. eumyota and three of $C$. antarctica were successfully sequenced; sequences were submitted to GenBank (accession numbers MG877558-MG877561).

Sequences obtained from GenBank and BOLD System databases were included in the analysis for comparison and as outgroups (Stach and Turbeville 2002; Kurabayashi et al. 2003; Monniot et al. 2011; Pyo et al. 2012; López-Legentil et al. 2015; Turon et al. 2016). Once aligned using the BioEdit program 7.0.5.3 (Hall 1999), sequences were collapsed into haplotypes; the number of polymorphic sites and haplotypes were calculated using the program DNAsp 6 (Rozas et al. 2017).

The average genetic diversity for each species was estimated using nucleotide $(\pi)$ and haplotype $(h)$ diversity according to Nei's (1987) method. Mean distances within and between species were calculated by Kimura's 2-parameter method (1000 bootstrap replicates) using MEGA 7 (Kumar et al. 2016). Two median-joining networks (one for C. eumyota samples, and one for samples of $C$. antarctica and C. suhmi) were generated to infer the most parsimonious phylogenetic relationships among concatenated mtDNA haplotypes using NETWORK v.4.6 (www.fluxus-engineering.com). Phylogenetic analyses 
were based on three approaches: maximum parsimony (MP), maximum likelihood (ML) and the Bayesian inferred (BI) analysis approach. For MP analyses, the TNT 1.5 program (Goloboff and Catalano 2016) was used. A heuristic search was performed with 300 random stepwise additions of taxa and tree bisection reconnection branch swapping. Standard bootstrap based on 1000 replications was used to assess the stability of each node. The best fitting models for the $\mathrm{ML}$ and $\mathrm{BI}$ analyses were selected using jModelTest version 2.1.9 (Darriba and Posada 2016), based on the Akaike information criteria and Bayesian information criteria, respectively. The selected model for both phylogeneticreconstruction strategies was GTR+G. For the ML analysis, bootstrap with 1000 replicates was performed with the general time-reversible (GTR) mode of substitution with gamma distributed rate variation among sites, as inferred from the best-fit models using MEGA 7 software. The $\mathrm{Bl}$ approach used four chains and the starting tree was random in MrBayes 3.2.5 (Zhou et al. 2011). The analysis was run for 100,000 generations, with a sample frequency of 100 . The first $25 \%$ of the trees were discarded as 'burn-in'. The posterior probabilities supporting the nodes were calculated. In the three methods, gaps were considered a fifth character.

\section{Results and discussion}

As expected, the $\mathrm{COI}$ sequences analysed support the morphological distinction between C. eumyota and C. antarctica (Alurralde et al. 2013; Monniot 2013): 70 mutations were detected separating samples from southern South America (attributed to C. eumyota) and those from Antarctica (C. antarctica and C. suhmi) (Figure 1). The interspecific distance was high between $C$. eumyota and their Antarctic relatives (22.2-23\%). The sequences of each species were then analysed separately, revealing 19 haplotypes in 20 sequences from $C$. eumyota. The 545 bp showed 22 polymorphic sites (14 parsimony informative sites) with a haplotype diversity $(h)$ of 0.995 and a nucleotide diversity $(\pi)$ of 0.01 . The partial sequence of $C$. eumyota from Argentina included in this work belongs to a new haplotype not observed previously either in Chile or elsewhere. Although this haplotype was the most similar to the three observed in Chile ( $\mathrm{H} 3, \mathrm{H} 6$ and $\mathrm{H} 8$ from Dupont et al. unpublished paper), differences were determined by six to eight mutations.

When the Antarctic sequences were analysed, intriguing relationships were observed among haplotypes. Three sequences of $713 \mathrm{bp}$ length of $C$. antarctica from Potter Cove (Antarctic Peninsula) were analysed together with two sequences from Terre Adélie (Adélie Land): one of the same species and one of C. suhmi. The sequences collapsed into five haplotypes, showing 40 polymorphic sites (four parsimony informative sites) with a haplotype diversity $(h)$ of 1.00 and a nucleotide diversity $(\pi)$ of 0.033 . The sequences from Potter Cove presented three exclusive haplotypes, differing by 32-34 mutations from that of Terre Adélie. Surprisingly, the sequence of $C$. suhmi (Terre Adélie) was more closely related to the sequences of $C$. antarctica from the far Potter Cove (only three to nine mutations) than to the sequence of $C$. antarctica from the same location. Genetic distances are summarised in Table 1. Considering the amount of mutations observed within the Antarctic set of haplotypes (Figure 1), further comparisons were conducted among these sequences. The intra- and interspecific distances were strikingly high among $C$. antarctica haplotypes when the haplotype from Terre Adélie was 


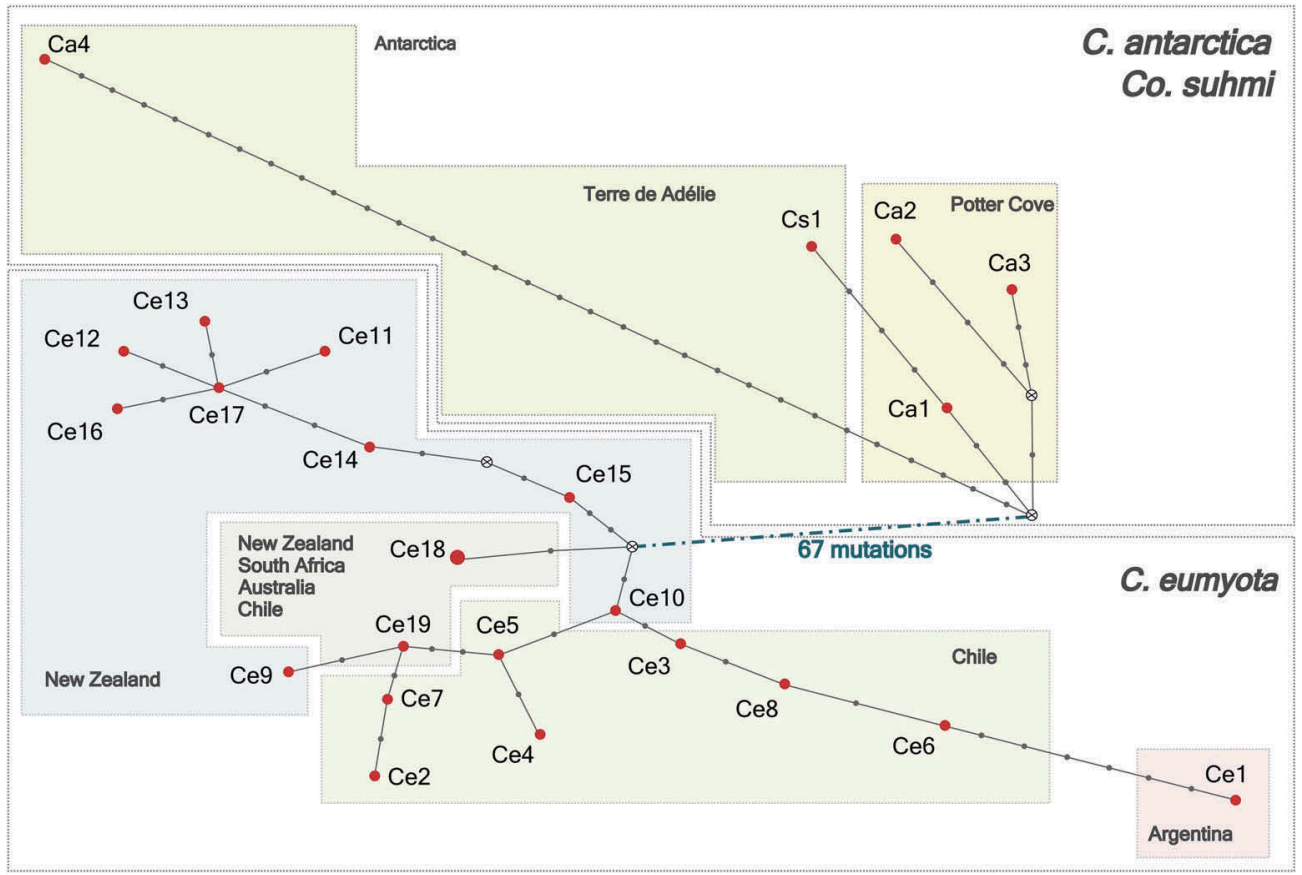

Figure 1. Haplotype network for corellid species from COI data. Localities where the haplotypes have been found are indicated in shaded polygons. Areas of the circles are proportional to the number of haplotypes. Small white crossed dots without name represent missing, probably unsampled, haplotypes or extinct sequences. Dots along the lines between circles represent one mutational step. For haplotype ID see Figure 2. Ce: Corella eumyota; Ca: Corella antarctica; Cs: Corynascidia suhmi.

included. Conversely, C. suhmi proved to be closest to the haplotypes of C. antarctica from the Antarctic Peninsula. The three phylogenetic approaches showed congruent and similar topologies (Figure 2). The clade that includes all individuals of $C$. eumyota is highly supported, as well as that representing $C$. antarctica and $C$. suhmi. The species C. suhmi is part of a well-supported group with C. antarctica from Potter Cove, clearly separated from $C$. antarctica from Terre Adélie.

The observed interspecific distance between C. eumyota and C. antarctica $(22.7 \%)$ exceeds the upper range of the interspecific divergence threshold to separate ascidian species (based on COI) discussed by Pérez-Portela et al. (2013 and references therein). This interspecific distance is also higher than the intraspecific distances found for C. eumyota (0.9\%) and C. antarctica (4.2\%), supporting the differentiation of both species using $\mathrm{COI}$ sequences as molecular markers. Despite the few DNA sequences available for Corella (highlighted by Monniot et al. 2011), this study shows lower variable intraspecific distances than previous reports (up to 20.77\%) for Antarctic and Sub-Antarctic ascidians (Dettai et al. 2011; Monniot et al. 2011). Our haplotype network and phylogenetic trees are the first to collate all available data, both molecular and morphological, and agree with the preliminary findings of Monniot et al. (2011) showing a close relationship between C. suhmi and C. antarctica (mentioned as C. eumyota in that study). Nonetheless, lower genetic differences were observed between $C$. antarctica (only 


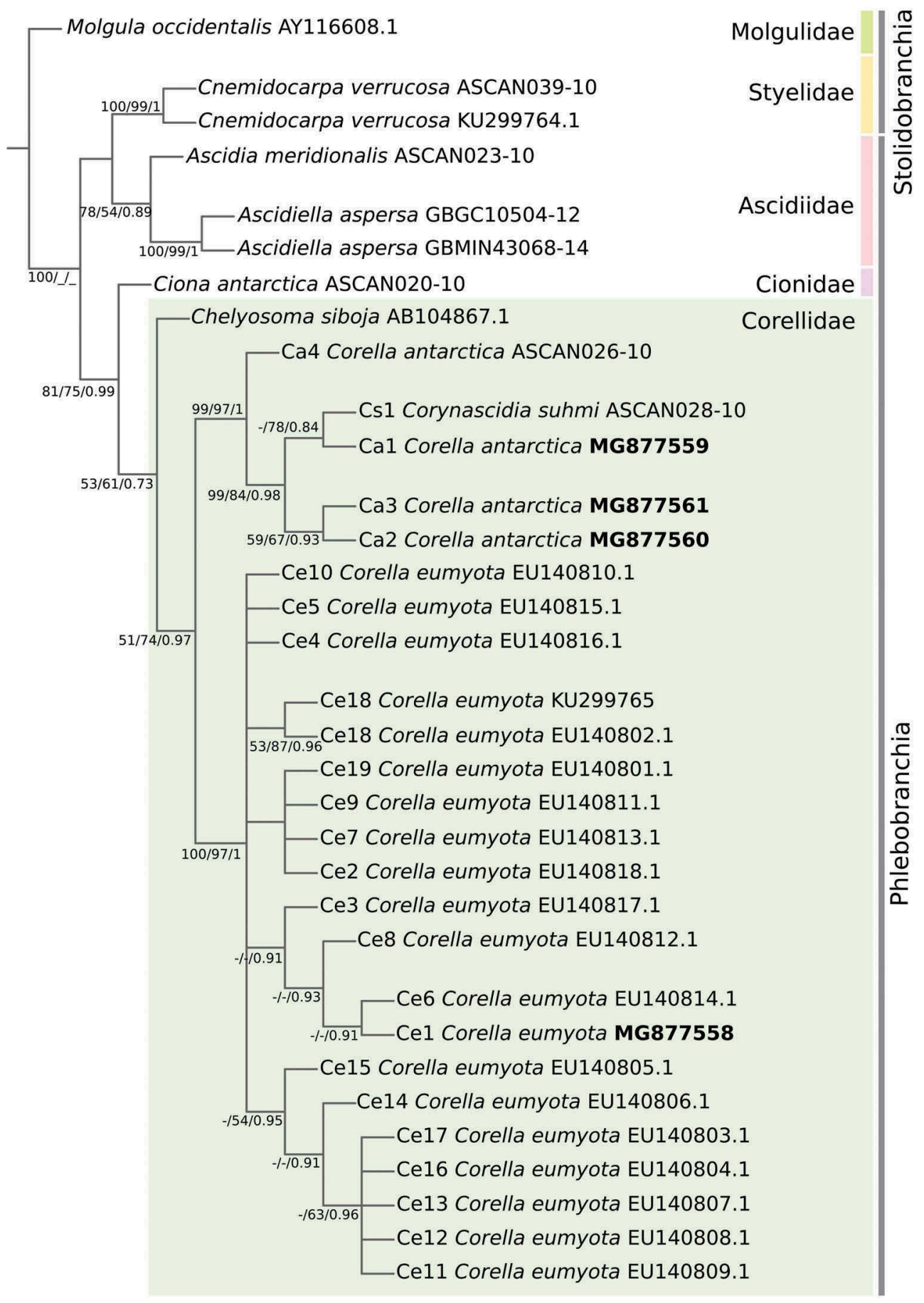

Figure 2. Maximum parsimony strict consensus tree of partial COI gene analysis. A total of 15 equally parsimonious trees were obtained (975 length; consistency index: 0.689; retention index: 0.767 ). Branches retrieved by the three methods are indicated by three support values on the nodes. Values represent bootstrap supports when $>50 \%$ for MP and ML analyses and posterior probabilities for $\mathrm{BI}$ when $>0.5$, in that order. Hyphen (-) denotes $<50 \%$ bootstrap values and posterior probabilities $<0.5$; underscore $(-$ ) indicates the nodes that did not appear in the tree. Specimen haplotype IDs and GenBank sequences or BOLD System accession numbers are shown. 
Table 1. Genetic distances among haplotypes of corellids.

\begin{tabular}{lll}
\hline Comparisons & Distance & Standard error \\
\hline Intraspecific & & \\
$\quad$ Corella eumyota & 0.009 & 0.003 \\
Corella antarctica & 0.0420 & 0.007 \\
Corella antarctica-Potter Cove & 0.010 & 0.003 \\
Interspecific & & \\
Corella eumyota/Corella antarctica & 0.227 & 0.028 \\
Corella eumyota/Corella antarctica-Potter Cove & 0.229 & 0.030 \\
Corella eumyota/Corella. antarctica-Terre Adélie & 0.222 & 0.030 \\
Corella eumyota/Corynascidia suhmi & 0.230 & 0.029 \\
Corella eumyota/Corella antarctica + Corynascidia suhmi & 0.228 & 0.029 \\
Corella antarctica/Corynascidia suhmi & 0.028 & 0.006 \\
Corella antarctica-Terre Adélie/Corynascidia suhmi & 0.068 & 0.013 \\
Corella antarctica-Potter Cove/Corynascidia suhmi & 0.015 & 0.005 \\
\hline
\end{tabular}

sequences from Potter Cove) and C. suhmi (1.2\%) than previously reported (6.25\%) by Monniot et al. (2011). Indeed, the latter value matches our estimation of interspecific distance between C. antarctica from Terre Adélie and C. suhmi (6.8\%). Hence, our results suggest that the specimens from Terre Adélie may have been misidentified or that there is an unnoticed cryptic species within the Corella genus.

The specimen of $C$. antarctica from Terre Adélie was collected deeper $(927 \mathrm{~m})$ than the $C$. suhmi specimen ( $214 \mathrm{~m})$, even though the latter is considered a deep-sea species (Kott 1969; Monniot et al. 2011). We dismiss a misidentification made by Monniot et al. (2011), who analysed four specimens of C. suhmi, since the general body shape of both species is markedly different, particularly in the presence of a peduncle in $C$. suhmi (Monniot et al. 2011; Maggioni et al. in prep.). Nonetheless, both Herdman (1882) and Van Name (1945), when re-describing C. suhmi, suggested that the species could be an abyssal form of Corella based on morphological traits. Monniot (2013) aroused suspicions about the individual variability of species of Corella from different locations for both shallow and deep specimens. Similar conclusions were reached by Alurralde et al. (2013), who found consistent variability patterns among South American C. eumyota populations. In addition to C. antarctica, Corella dohrni and Corella benedeni (Van Beneden and Selys Longchamps 1913) were also proposed as Antarctic Corella species, and were finally synonymised with $C$. eumyota under the assumption of high intraspecific variability (Ärnbäck-Christie-Linde 1938; Van Name 1945). Monniot (2013) highlighted the need for further investigation to determine if all the specimens attributed to $C$. antarctica represent a single species around the Antarctic Continent. The high genetic distance observed between $C$. antarctica sequences from Potter Cove and Terre Adélie indicates that we may be dealing with a genus that is more varied than previously thought throughout the Southern Hemisphere.

Our analyses of $\mathrm{CO}$ sequences support the taxonomic status of $\mathrm{C}$. eumyota and C. antarctica, but they also yielded intriguing insights into the entity of Corella species from Antarctic waters. The present study did not aim to make a taxonomic review of the family Corellidae, but clearly underlines the need for a deeper appraisal, since we may be dealing with more species than previously thought, especially in Antarctica. Thus, there is still work clearly to be done on the taxonomical status of these Antarctic entities, as happened with C. antarctica (Alurralde et al. 2013; Monniot 2013). Several authors have stated that distinguishing corellids is taxonomically challenging (Herdman 1886; 
Van Name 1945; Monniot 2013), as the results presented here have demonstrated. Given the lack of sufficient material for study (from a classical taxonomic point of view) and of genetic data, there is a need for deeper and more extensive investigation on this matter. The identification of species is one of the greatest obstacles to understanding broader patterns of invasion, which highlights the importance of more rigorous and integrative taxonomic studies. In the current context of global changes in the marine biota and the spread of invasive species, proper species identification becomes indispensable to avoid uncertainty concerning the status of a given species, i.e. native, invasive or cryptogenic.

\section{Acknowledgements}

We want to thank M Ruiz, JJ Martinez and G Rautenberg for their important contribution. We are also very grateful for the French translation performed by MA Caballero and A Leche, and to $\mathrm{J}$ Heywood for his English revision.

\section{Disclosure statement}

No potential conflict of interest was reported by the authors.

\section{Funding}

This work was supported by Consejo Nacional de Investigaciones Científicas y Técnicas (CONICET), Universidad Nacional de Córdoba and Instituto Antártico Argentino, and partially funded by Secretaría de Ciencia y Técnica - Universidad Nacional de Córdoba (SECyT-UNC) [30720150100406CB]; Proyectos de Investigación Plurianuales (PIP) CONICET [20130100508]; Agencia Nacional de Promoción Científica y Tecnológica - Dirección Nacional del Antártico (ANPCyT-DNA) Proyectos de Investigación Científica y Tecnológica Orientados (PICTO) [PICTO 2010-0019]; IDEAWILD and Professional Association of Diving Instructors (PADI) Foundation [\#32778].

\section{ORCID}

Gastón Alurralde (10) http://orcid.org/0000-0002-0332-3978

María Carla de Aranzamendi (i) http://orcid.org/0000-0003-4442-0384

Anabela Taverna (1) http://orcid.org/0000-0001-9433-1190

Tamara Maggioni (D) http://orcid.org/0000-0002-4936-5970

Marcos Tatián (1) http://orcid.org/0000-0002-9092-9184

\section{References}

Alurralde G, Torre L, Schwindt E, Castilla JC, Tatián M. 2013. A re-evaluation of morphological characters of the invasive ascidian Corella eumyota reveals two different species at the tip of south America and in the South Shetland Islands, Antarctica. Polar Biol. 36:957-968.

Arenas F, Bishop JDD, Carlton JT, Dyrynd PJ, Farnham WF, Gonzalez DJ, Jacobs MW, Lambert C, Lambert G, Nielsen SE, et al. 2006. Alien species and other notable records from a rapid assessment survey of marinas on the south coast of England. J Mar Biol Assoc UK. 86:1329-1337.

Ärnbäck-Christie-Linde A. 1938. Ascidiacea, pat I. Zool Results Swedish Antarct Expedit 1901-1903. 3:1-54. 
Bishop JD, Roby C, Yunnie AL, Wood CA, Lévêque L, Turon X, Viard F. 2013. The Southern Hemisphere ascidian Asterocarpa humilis is unrecognised but widely established in NW France and Great Britain. Biol Invasions. 15:253-260.

Brewin B. 1946. Ascidians in the vicinity of the Portobello marine biological station, Otago harbour. Trans R Soc N Z. 76:87-131.

Bucklin A, Steinke D, Blanco-Bercial L. 2011. DNA barcoding of marine metazoa. Ann Rev Mar Sci. 3:471-508.

Collin SB, Oakley JA, Sewell J, Bishop JDD. 2010. Widespread occurrence of the non-indigenous ascidian Corella eumyota Traustedt, 1882 on the shores of Plymouth Sound and Estuaries Special Area of Conservation, UK. Aquat Invasions. 5:1-5.

Darriba D, Posada D. 2016. jModelTest 2 Manual v0.1.10. Parallel Comput. 9:772.

Dettai A, Adamowizc SJ, Allcock L, Arango CP, Barnes DK, Barratt I, Chenuil A, Couloux A, Cruaud C, David $B$, et al. 2011. DNA barcoding and molecular systematics of the benthic and demersal organisms of the CEAMARC survey. Polar Sci. 5:298-312.

Dupont L, Viard F, David P, Bishop JDD. 2007. Combined effects of bottlenecks and selfing in populations of Corella eumyota, a recently introduced sea squirt in the English Channel. Divers Distrib. 13:808-817.

Folmer O, Black M, Heah W, Lutz R, Vrijenhoek R. 1994. DNA primers for amplification of mitochondrial cytochrome $\mathrm{C}$ oxidase subunit I from diverse metazoan invertebrates. Mol Marine Biol Biotechnol. 3:294-299.

Goloboff PA, Catalano SA. 2016. TNT version 1.5, including a full implementation of phylogenetic morphometrics. Cladistics. 32:221-238.

Hall TA. 1999. BioEdit: a user-friendly biological sequence alignment editor and analysis program for Windows 95/98/NT. Nucleic Acids Symp Ser. 41:95-98.

Hartmeyer R. 1924. Ascidiacea. Copenhagen: Hagerup.

Herdman WA. 1882. Report on the Tunicata collected during the voyage of HMS "Challenger" during the years 1873-1878. Part. I, Ascidiae simplices. Rep sci Res Voy HMS Chall Zool 6(17): 1-296.

Herdman WA. 1886. Report on the Tunicata collected during the voyage of the H.M.S. Challenger during the years 1873-1876. P. II - Ascidiae compositae. In: Thompson CW, Murray J (Eds). Report on the scientific results of the years 1873-1876. 14: 1-429. London, Johnson Reprint Comp. Ltd.

Herdman WA. 1910. Tunicata. National Antarctic Expedition (S.S. Discovery) 1901-1904. Nat Hist. $5: 1-26$.

Kott P. 1969. Antarctic Ascidiacea. Antarct Res Ser. 13:1-239.

Kumar S, Stecher G, Tamura K. 2016. MEGA7: molecular evolutionary genetics analysis version 7.0 for bigger datasets. Mol Biol Evol. 33:1870-1874.

Kurabayashi A, Okuyama M, Ogawa M, Takeuchi A, Jing Z, Naganuma T, Saito Y. 2003. Phylogenetic position of a deep-sea ascidian, Megalodicopia hians, inferred from the molecular data. Zool Sci. 20:1243-1247.

Lambert CC, Lambert IM, Lambert G. 1995. Brooding strategies in solitary ascidians: corella species from north and south temperate waters. Can J Zool. 73:1666-1671.

Lambert G. 2004. The south temperate and Antarctic ascidian Corella eumyota reported in two harbours in north-western France. J Mar Biol Assoc UK. 84:239-241.

Lambert G, Lambert CC, Abbott DP. 1981. Corella species in the American Pacific Northwest: distinction of C. inflata Huntsman, 1912 from C. willmeriana Herdman, 1898 (Ascidiacea, Phlebobranchia). Can J Zool. 59:1493-1504.

Locke A. 2009. A screening procedure for potential tunicate invaders of Atlantic Canada. Aquat Invasions. 4:71-79.

López-Legentil S, Legentil ML, Erwin PM, Turon X. 2015. Harbor networks as introduction gateways: contrasting distribution patterns of native and introduced ascidians. Biol Invasions. 17:1623-1638.

McGlashan DJ, Ponniah M, Cassey P, Viard F. 2008. Clarifying marine invasions with molecular markers: an illustration based on mtDNA from mistaken calyptraeid gastropod identifications. Biol Invasions. 10:51-57. 
Minchin D. 2007. A checklist of alien and cryptogenic aquatic species in Ireland. Aquat Invasions. 2:341-366.

Monniot C, Monniot F. 1994. Additions to the inventory of eastern tropical Atlantic ascidians; arrival of cosmopolitan species. Bull Mar Sci. 54:71-93.

Monniot F. 1994. Ascidies de Nouvelle-Calédonie. XV: le genre Didemnum. Bulletin du Muséum d'Histoire Naturelle Paris. 16:299-344.

Monniot F. 2013. The genus Corella (Ascidiacea, Phlebobranchia, Corellidae) in the Southern Hemisphere with description of a new species. Zootaxa. 3702:135-149.

Monniot F, Dettai A, Eleaume M, Cruaud C, Ameziane N. 2011. Antarctic Ascidians (Tunicata) of the French-Australian survey CEAMARC in Terre Adélie. Zootaxa. 2817:1-54.

Nagar AE, Huys R, Bishop JDD. 2010. Widespread occurrence of the Southern Hemisphere ascidian Corella eumyota Traustedt, 1882 on the Atlantic coast of Iberia. Aquat Invasions. 5:1-5.

Nei M. 1987. Molecular evolutionary genetics. New York: Columbia university press.

Pérez-Portela R, Arranz V, Rius M, Turon X. 2013. Cryptic speciation or global spread? The case of a cosmopolitan marine invertebrate with limited dispersal capabilities. Sci Rep. 3:3197.

Pyo J, Lee T, Shin S. 2012. Two newly recorded invasive alien ascidians (Chordata, Tunicata, Ascidiacea) based on morphological and molecular phylogenetic analysis in Korea. Zootaxa. 3368:211-228.

Rozas J, Ferrer-Mata A, Sánchez-Del Barrio JC, Guirao-Rico S, Librado P, Ramos-Onsins SE, SánchezGracia A. 2017. DnaSP 6: DNA sequence polymorphism analysis of large data sets. Mol Biol Evol. 34:3299-3302.

Sanamyan KE, Sanamyan NP. 2002. Deep-water ascidians from the south-western Atlantic (RV Dmitry Mendeleev, cruise 43 and Academic Kurchatov, cruise 11). J Nat Hist. 36:305-359.

Sanamyan KE, Sanamyan NP. 2005. Deep-water ascidians from the North Atlantic (RV Academic Keldysh, cruise 46 and 49). J Nat Hist. 39:2005-2021.

Sluiter CP. 1905. Note préliminaire sur les ascidiens Holostomates de I'Expedition Antarctique Française commandée par le Dr. Charcot. Bull Mus Natl Hist Nat Paris 11(6):470-475.

Stach T, Turbeville JM. 2002. Phylogeny of Tunicata inferred from molecular and morphological characters. Mol Phylogenet Evol. 25:408-428.

Traustedt MPA. 1882. Ventindiske Ascidiae simplices. Først Afd. (Phallusidae). Vidensk Meddel Naturhist Foren Kjöbenhaven, ann 1881:257-288.

Turon X, Cañete Jl, Sellanes J, Rocha RM, López-Legentil S. 2016. Ascidian fauna (Tunicata, Ascidiacea) of subantarctic and temperate regions of Chile. Zootaxa. 4093:151-180.

Van Beneden E, de Selys Longchamps M. 1913. Zoologie: Tuniciers, Caducichordata (Ascidiacés et Thaliacés). Résultats du Voyage du S.Y. Belgica en 1897-1898-1899 sous le commandenment de A. Gerlache de Gomery: Rapports Scientifiques (1901-1913).

Van Name WG. 1945. The North and South American ascidians. Bull Am Mus Nat His. 84:1-476. Varela MM, De Matos-Pita SS, Ramil F, Ramos-Esplá AA. 2007. New report of the Antarctic ascidian Corella eumyota (Tunicata, Ascidiacea) in Galicia coast (NW Spain). Mar Biodivers Rec. 1:e59.

Zhou J, Liu X, Stones DS, Xie Q, Wang G. 2011. MrBayes on a graphics processing unit. Bioinformatics. 27:1255-1261. 